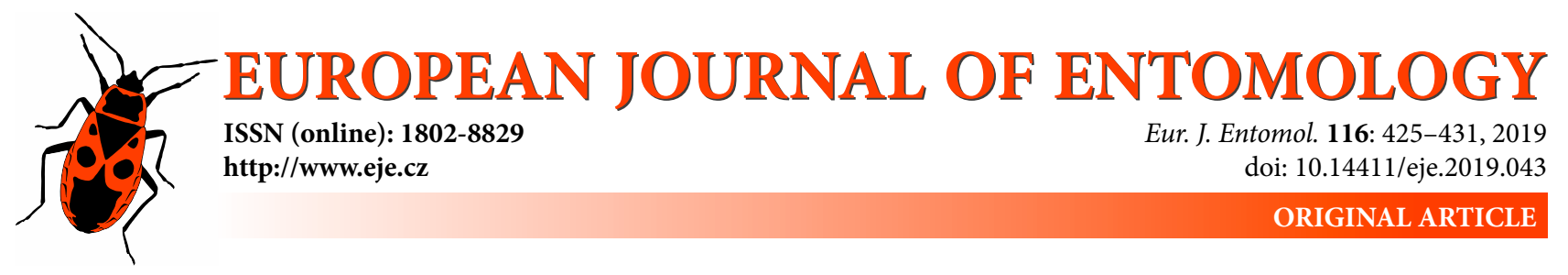

\title{
Sampling of flower-visiting insects: Poor correspondence between the catches of colour pan-trap and sweep netting
}

\author{
HiLda-Linn BERGLUND and Per MILBERG* \\ IFM Biology, Conservation Ecology Group, Linköping University, 58183 Linköping, Sweden; e-mails: hilda.linn@hotmail.com, \\ per.milberg@liu.se
}

\begin{abstract}
Key words. Apoidea, Cetoniidae, Cerambycidae, Lepturinae, Syrphidae, flower visiting, sweep netting, pan-trap, sampling, selectivity
\end{abstract}

\begin{abstract}
Pollinating insects are important and therefore, it is important to be able to assess and monitor changes in their abundance. Consequently, it is essential that the methods used to collect data have some level of precision and are accurate. In the present study, two commonly used methods: colour pan-traps and sweep netting along transects, were compared. A total of 1775 specimens of 120 species of four insect families were caught in twelve clear-cuts in southern Sweden. Overall, Lepturinae (Cerambycidae; 5 species) and Cetoniidae (Scarabaeidae; 2) were trapped in larger numbers by pan-traps and Syrphidae (62) and Apoidea, both social (10) and solitary (41), by sweep netting. The catches of none of the above groups of insects by the two methods were correlated. These results show that the composition of catches of the two methods are very different, which has implications when choosing a method for sampling or monitoring and comparing and analysing published data.
\end{abstract}

\section{INTRODUCTION}

Pollinating insects perform essential tasks for wild plants and man alike (Klein et al., 2007; Gallai et al., 2008; Aizen et al., 2009) and decreases in the abundance of pollinators (Fitzpatrick et al., 2007; Kluser \& Peduzzi, 2007; Potts et al., 2010; Vanbergen et al., 2013) points to the need for monitoring and surveying flower-visiting insects (McCravy, 2018). Methods used to survey pollinator populations such as Malais and suction traps indiscriminately catch large numbers of insects, which is less useful when targeting pollinating insects (Campbell \& Hanula, 2007). On the other hand, walking along transects does not work well for smaller and more mobile species. So, the two methods most likely to be used are sweep netting along transects and pan-traps. Pan-traps, that are specifically targeting pollinators, involve luring them to liquid-filled colourful pans during their search for sources of nectar. Pan-trapping is often described positively, e.g. "... one of the most effective passive sampling techniques and ideal for long-term monitoring" (Falk, 2015, p. 44) and is promoted by FAO for monitoring (LeBuhn et al., 2016).

All insect sampling methods are to some degree selective and it is important to understand the nature of the selectivity. On the other hand, it is extremely complex to assess insect catches from the point of view of accuracy (i.e. how well a catch reflects population sizes at a site). On the other hand, it is often sufficient to focus on precision, i.e. to what extent a result can be reproduced. Another approach is to compare two or three potential methods, to better understand the unique bias in the data that each produce (Wood et al., 2015). When it comes to sweep netting and colour pan-traps, previous studies report conflicting finds: pan-traps catch more species than sweep netting (Sobota \& Twardowski, 2004; Wilson et al., 2008; Nielsen et al., 2011; Spafford \& Lortie, 2013), fewer species (Cane et al., 2000; Roulston et al., 2007; Namaghi \& Husseini, 2009; Popic et al., 2013) and equal numbers of species (Westphal et al., 2008; Grundel et al., 2011). These conflicting results could potentially be due to differences in the pan-trap methodology (e.g. different colours and type of colours; placed on or above the ground; different types and shapes of pans; Tuell \& Isaacs, 2009; Joshi et al., 2015, Shrestha et al., 2019) and for sweep netting (size of sweep net; whether only flowers are targeted or vegetation), or simply due to differing sampling effort.

The aim of the present study was to compare the catches of colour pan-traps and sweep netting along transects. We sampled clear-cuts in boreal forests, differing in land use history thereby achieving a gradient in flower abundance and potentially a greater diversity of flower-visiting insects. We considered five taxonomic groups: Syrphidae, solitary Apoidea, social Apoidea, Lepturinae and Cetoniideae. The

\footnotetext{
* Corresponding author; e-mail: per.milberg@liu.se
} 

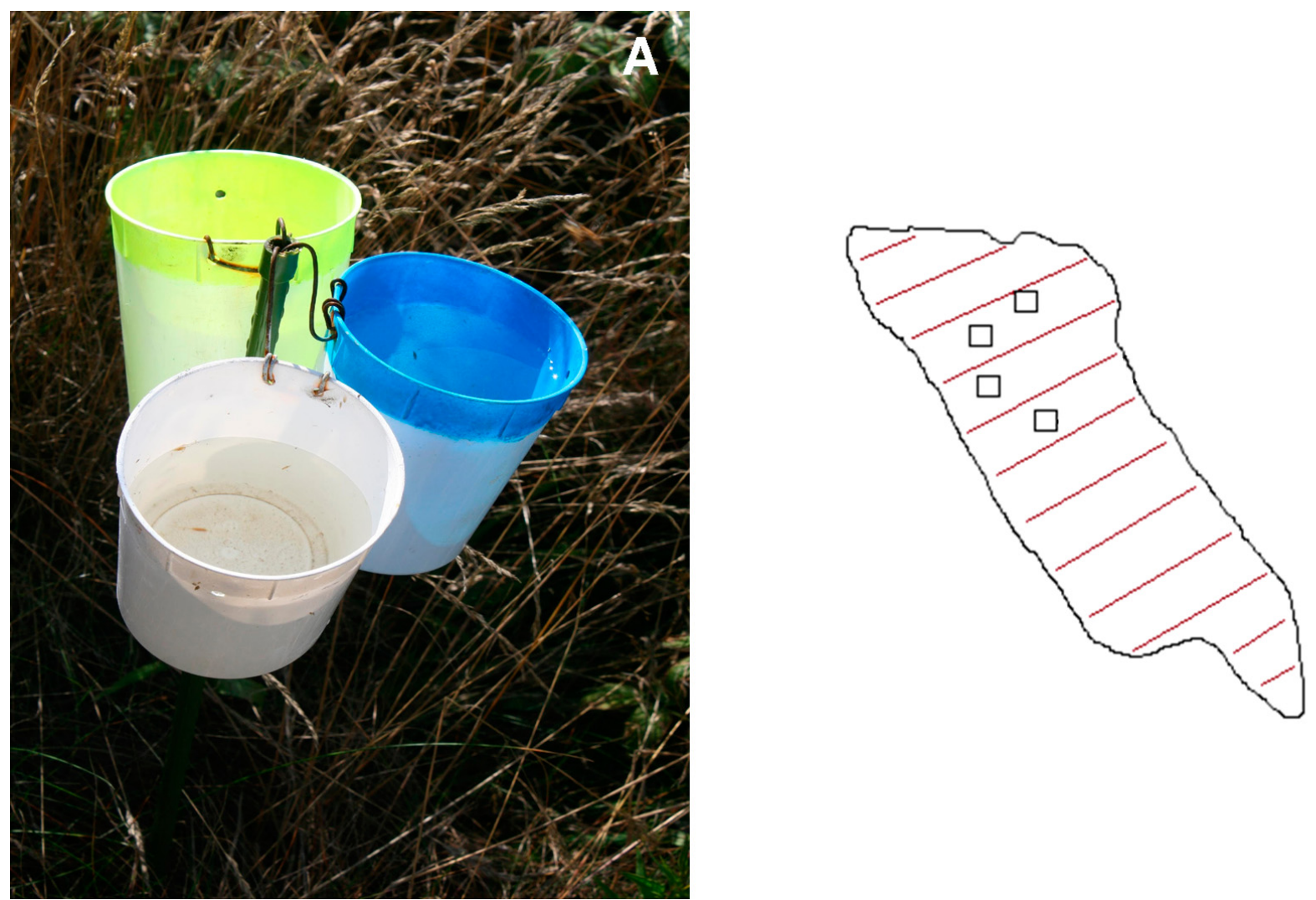

Fig 1. A - a set of three pan-traps with one painted blue, one yellow and one white mounted on a metal rod; the small drainage holes are visible. B - an example of a clear-cut with the set of pan-traps (squares) and transects (red lines) indicated.

goal was to identify biases in these two methods. We also tested the assumed negative bias in the catches of large insects by pan-traps (Cane, 2001; Westphal et al., 2008) and small insects by sweep netting. We did this by regressing species-wise odds ratios (for being caught) on body length.

\section{MATERIAL AND METHODS}

\section{Study sites}

This study was conducted in twelve clear-cuts in hemi-boreal forests in the province of Östergötland, southern Sweden. The landscape consists mainly of coniferous forest, but is mixed with lakes, bogs, small patches of seminatural grasslands and arable fields (Ibbe et al., 2011; Milberg et al., 2019). The selected clearcuts had an area of 2-6 ha, had been logged 4-6 years previously, and were situated at a minimum distance of $300 \mathrm{~m}$ from nearest seminatural grassland. To achieve a gradient in the abundance of flower-visiting insect, we included clear-cuts in areas that were coniferous forest and those that were hay meadows in the 1870 s (Jonason et al., 2014, 2016). Since then, there was at least one generation of spruce-dominated forest at these sites, for a minimum of 70 and a maximum of about 140 years (Ibbe et al., 2011).

The cover of flowers in the clear-cuts was assessed by using ca $1001-\mathrm{m}^{2}$ plots (Berglund et al., in prep.) and ranged from 0.000237 to $0.001329 \%$ (average $0.000494 \%$ ) at the time the insects were sampled.

\section{Pan-traps}

The pans used to collect flower-visiting insects were painted in one of three UV-reflecting colours: blue, white or yellow (Soppec, Sylva mark fluo marker, Nersac, France). The pans had a volume of $0.5 \mathrm{~L}$ (diameter $8.7 \mathrm{~cm}$ ) and were filled with toxic-free propylene glycol ( $40 \%$ concentration). This liquid preserves the insects caught and decreases the surface tension. A small opening $(4 \mathrm{~mm}$ in diameter) at the top of each bowl was made to ensure that rainwater could drain away. One set of pan-traps consisted of three pans, one of each colour, placed on a steel stick (Fig. 1a). Four sets of pan-traps were placed in each clear-cut at the same height as the vegetation (often $30-50 \mathrm{~cm}$ ) and in places that were typical of each clear-cut. Pans were set for a week in early August 2015. Of the 48 sets of pan-traps used, two were knocked down by animals and not included in the analysis.

\section{Sweep netting}

At the beginning of August, all clear-cuts were sweep netted, at most 5 days before or after the period the pan-traps were set. The sweep netting was carried out along transects $25 \mathrm{~m}$ apart, which included the whole of each clear-cut (Fig. 1b) at a pace of $100 \mathrm{~m}$ per $4 \mathrm{~min}$. The transect-walk occurred between 07.00 and 13.00 GMT (9.00-15.00 Swedish summer time) when it was sunny, at least $17^{\circ} \mathrm{C}$ and the wind strength less than four on the Beaufort scale (Beaufort scale three: only tiny branches and leaves are moving). Syrphidae, Apoidea and Lepturinae were caught, while Cetoniidae were only counted, within $1 \mathrm{~m}$ of the transect. If the sun became covered by clouds, the collector waited until the sun reappeared and then resumed walking.

\section{Data analyses}

Specimens caught were identified to species level and those unidentified were not included in this study. However, among Cetoniidae only Trichius fasciatus was identified to species while the remaining specimens were considered as a group, henceforth called Cetoniidae spp., which is likely to consist of three species at the sites studied (Protaetia marmorata, Cetonia aurata, Protaetia metallica). Insects belonging to non-target taxonomic groups caught during sweep netting were not included although 
they could be numerous in the pan-trap catches (e.g. Vespoidea, Lepidoptera, small Coleoptera).

Before analyses, the following steps were taken to produce comparable data: (i) Pan-traps: as two sets of traps were lost at one site, average specimens per set of pan-traps were calculated. (ii) Sweep netting: as the sizes of the sites varied and hence transect length, we calculated number of specimens per ha, assuming the transects covered $8 \%$ of each clear-cut.

Correlation between the catches of the two sampling methods

To compare the catches using the two methods, correlation coefficients were calculated for social Apoidea, solitary Apoidea, Lepturinae and Syrphidae (Cetoniidae was judged too scarce for a meaningful analysis).

\section{Occurrence data}

As insects often aggregate, the actual number of specimens recorded might inflate differences between methods and sites. Hence, a more conservative type of data is the frequency of occurrence. We therefore considered the number of clear-cuts where a species was recorded using each of the two methods. From this we calculated the odds of recording a species with pan-traps and sweep netting, and from this the $\ln$ (odds ratio) was calculated, positive values for which indicate higher odds that pan-traps captured more than sweep netting. The confidence interval of the odds ratio allows an informal significance testing, but the statistical power of this approach is low, given that only 12 clear-cuts were sampled. Species-wise odds ratios were finally combined into group-wise odds ratios, using meta-analyses methods that weighted the frequency of occurrence of species. This analysis did not include sampling effort, which differed as two sets of pantraps were lost, the greater number of specimens recorded when sweep netting, or the pair-wise nature of the data.

Species-wise odds ratios were regressed to test whether they varied with body mass. We included those species for which body lengths are recorded in the literature (mainly Falk, 2015 and Wikipedia for Apoidea, Bartsch et al., 2009a, b for Syrphidae, Lindhe et al., 2010, for Lepturinae), and calculated averages when ranges were given and sexes differed in length. We then regressed the results for: (i) all species $(\mathrm{N}=116)$, (ii) social Apoidea $(\mathrm{N}=9)$, (iii) solitary Apoidea (39) and (iv) Syrphidae (62).

\section{RESULTS}

A total of 1184 individuals belonging to 108 species were caught by sweep netting, compared to 591 belonging to 48 species by the pan-traps (Table 1). Even after adjusting for differing sampling efforts in terms of the number of sets of pan traps and sizes of the clear-cuts, the average number of specimens recorded using sweep netting was double that recorded using pan-traps (Table 1). In terms of species, similar patterns emerge: 1 of 2 Cetoniidae and 4 of 5 Lepturinae were significantly more likely to occur in pan traps than to be recorded using sweep netting (Table 2). In contrast, 2 of the 10 social Apoidea, 2 of the 41 solitary Apoidea and 9 of the 62 Syrphidae were significantly more likely to be caught by sweep netting than by pan traps (Table 2).

In terms of abundance, there were no significant correlations between numbers caught in pan traps and during sweep netting (Table 1).

The occurrence data clearly showed that Cetoniidae and Lepturinae were much better represented in the catches of pan-trap than in those of sweep netting (Table 2). The op-
Table 1. Total number of specimens and species recorded in 46 sets of pan-traps and by sweep netting in 12 clear-cuts.

\begin{tabular}{|c|c|c|c|c|}
\hline & Pan-traps & Sweep netting & Total & \\
\hline Specimens & 591 & 1184 & 1775 & \\
\hline \multirow[t]{2}{*}{ Species } & 48 & 108 & 120 & \\
\hline & $\begin{array}{c}\text { Average per se } \\
\text { of pan-traps }\end{array}$ & $\begin{array}{l}\text { Average per } \\
\text { hectare }\end{array}$ & $\begin{array}{l}\text { Correlation } \\
\text { coefficient }\end{array}$ & $\mathrm{P}$ \\
\hline Lepturinae & 8.5 & 2.7 & 0.355 & 0.257 \\
\hline Cetoniidae & 1.3 & 0.0 & & \\
\hline Social Apoidea & 1.2 & 6.2 & 0.204 & 0.524 \\
\hline Solitary Apoidea & 1.02 & 2.1 & 0.257 & 0.368 \\
\hline Syrphidae & 0.7 & 14.5 & -0.127 & 0.695 \\
\hline Total & 12.8 & 25.5 & 0.198 & 0.521 \\
\hline
\end{tabular}

posite was true for Syrphidae and both types of Apoidea (Table 2).

There was no significant relationship between body lengths and $\ln (\mathrm{OR})$ in any of the four tests conducted: (i) all species $\left(\mathrm{F}_{(1,114)}=3.126 ; \mathrm{P}=0.0797\right.$; slope 0.641), (ii) social Apoidea $\left(\mathrm{F}_{(1,7)}=0.972 ; \mathrm{P}=0.357\right.$; slope 0.0818$)$, (iii) solitary Apoidea $\left(\mathrm{F}_{(1,37)}=0.477 ; \mathrm{P}=0.494\right.$; slope 0.137$)$, (iv) Syrphidae $\left(\mathrm{F}_{(1,60)}=0.908 ; \mathrm{P}=0.344\right.$; slope 0.02039). Note that the estimated slope was always positive, i.e. increased odds of being caught by pan-traps with increase in body length.

\section{DISCUSSION}

None of the five taxonomic groups sampled were recorded similarly using pan-traps and sweep netting; and two groups (Cetoniidae, Lepturinae) were "over-sampled" by pan-traps and three groups (Syrphidae, social Apoidea, solitary Apoidea) were "under-sampled". So, for a multi-taxa study a combination of both methods would be the best option (cf. Spafford \& Lortie, 2013). However, combining such data results in two numerical problems. First, only sweep netting data can be converted to densities, so one is left with a combined species list, and presence/absence data. Second, the sampling effort is difficult to compare if one method catches many more specimens. Consequently, catches using the two methods could not, strictly speaking, be numerically compared (cf. Popic et al., 2013, Wood et al., 2015) and combining them would result in a substantial loss of numerical information. In the present study, the two catches involved similar sampling efforts, but sweep netting caught more individuals (and consequently more species) than the pan-traps. Considering only the Apoidea, only $21 \%$ of the specimens were caught by the pan traps (data not shown), which confirms reports by Cane et al. (2000) and Roulston et al. (2007), but see Westphal et al. (2008) who report only small differences between different methods. Another example, 785 specimens of Syrphidae were caught using sweep netting but only 32 by the pantraps. Hence, to achieve a similar catch using pan-traps would require a 20 -fold increase in the number of traps. In conclusion, combining the two methods is excellent for achieving a more comprehensive species list, but results in low quality numerical data. It also raises the issue of the marked difference in the sizes catches using the two methods. In studies using these two methods the follow- 
Table 2. Odds ratio for groups and individual species caught by sweep netting and pan traps in clear-cuts. A positive In(odds ratio) means the odds are higher for being caught in a pan trap than by sweep netting.

\begin{tabular}{|c|c|c|c|c|c|c|c|}
\hline & $\begin{array}{l}\text { In (odds } \\
\text { ratio) }\end{array}$ & $-\mathrm{Cl}_{95 \%}$ & $+\mathrm{Cl}_{95 \%}$ & $p$-Value & & $\begin{array}{l}\text { No. of } \\
\text { species }\end{array}$ & $\begin{array}{l}\text { No. of specimens } \\
\text { Traps/Netting }\end{array}$ \\
\hline Cetoniidae & 3.896 & 1.802 & 5.991 & 0.00027 & $* \star \star *$ & 2 & $62 / 1$ \\
\hline Lepturinae & 3.056 & 1.739 & 4.374 & 0.00001 & $* \star *$ & 4 & $397 / 139$ \\
\hline Social Apoidea & -0.984 & -1.631 & -0.338 & 0.00284 & ** & 10 & $55 / 267$ \\
\hline Solitary Apoidea & -0.568 & -1.007 & -0.120 & 0.01116 & * & 42 & $74 / 153$ \\
\hline Syrphidae & -1.742 & -2.118 & -1.367 & 0.00000 & $* * *$ & 62 & $32 / 670$ \\
\hline CETONIIDAE & & & & & & Freq. Pan $/ \mathrm{N}$ & No. of specimens \\
\hline Cetoniidae spp. & 2.909 & -0.125 & 5.942 & 0.06018 & & $5 / 0$ & 7 \\
\hline Trichius fasciatus & 4.796 & 1.901 & 7.691 & 0.00117 & $* *$ & $11 / 1$ & 56 \\
\hline \multicolumn{8}{|l|}{ LEPTURINAE } \\
\hline Anastrangalia reyi/A. sanguinolenta & 2.708 & 0.705 & 4.711 & 0.00805 & ** & $9 / 2$ & 63 \\
\hline Leptura quadrifasciata & 3.219 & 0.190 & 6.247 & 0.03724 & * & $6 / 0$ & 23 \\
\hline Stenurella melanura & 3.219 & 0.190 & 6.247 & 0.03724 & * & $12 / 6$ & 274 \\
\hline Stictoleptula maculicornis & 3.529 & 0.496 & 6.562 & 0.02259 & * & $7 / 0$ & 14 \\
\hline Stictoleptura rubra & & & & & & $12 / 12$ & 162 \\
\hline \multicolumn{8}{|l|}{ SOCIAL APOIDEA } \\
\hline Bombus pascuorum & -2.220 & -5.301 & 0.861 & 0.15780 & & $9 / 12$ & 119 \\
\hline Apis mellifera & -1.792 & -3.566 & -0.018 & 0.04778 & * & $4 / 9$ & 100 \\
\hline Bombus terrestris/cryptarum/lucorum/magnus & -1.792 & -3.566 & -0.018 & 0.04778 & * & $4 / 9$ & 33 \\
\hline Bombus norvegicus & -1.705 & -4.078 & 0.668 & 0.15913 & & $1 / 4$ & 5 \\
\hline Bombus sylvarum & -1.705 & -4.078 & 0.668 & 0.15913 & & $1 / 4$ & 9 \\
\hline Bombus lapidaries & -0.788 & -3.337 & 1.760 & 0.54429 & & $1 / 2$ & 7 \\
\hline Bombus sylvestris & -0.511 & -2.514 & 1.492 & 0.61719 & & $2 / 3$ & 11 \\
\hline Bombus pratorum & -0.336 & -1.948 & 1.275 & 0.68241 & & $6 / 7$ & 23 \\
\hline Bombus hortorum & 0.000 & -2.147 & 2.147 & 1.00000 & & $2 / 2$ & 4 \\
\hline Bombus soroeensis & 0.000 & -1.848 & 1.848 & 1.00000 & & $3 / 3$ & 11 \\
\hline \multicolumn{8}{|l|}{ SOLITARY APOIDEA } \\
\hline Andrena subopaca & -3.529 & -6.562 & -0.496 & 0.02259 & * & $0 / 7$ & 13 \\
\hline Lasioglossum fratellum & -3.091 & -5.464 & -0.718 & 0.01068 & * & $1 / 8$ & 18 \\
\hline Andrena denticulata & -2.220 & -5.301 & 0.861 & 0.15780 & & $0 / 3$ & 6 \\
\hline Hylaeus rinki & -2.220 & -5.301 & 0.861 & 0.15780 & & $0 / 3$ & 3 \\
\hline Andrena fuscipes & -1.784 & -4.929 & 1.361 & 0.26632 & & $0 / 2$ & 2 \\
\hline Lasioglossum calceatum & -1.784 & -4.929 & 1.361 & 0.26632 & & $0 / 2$ & 2 \\
\hline Macropis europaea & -1.784 & -4.929 & 1.361 & 0.26632 & & $0 / 2$ & 2 \\
\hline Andrena tarsata & -1.705 & -4.078 & 0.668 & 0.15913 & & $1 / 4$ & 6 \\
\hline Halictus rubicundus & -1.299 & -3.728 & 1.129 & 0.29437 & & $1 / 3$ & 7 \\
\hline Lasioglossum leucopus & -1.299 & -3.728 & 1.129 & 0.29437 & & $1 / 3$ & 4 \\
\hline Andrena fucata & -1.182 & -4.481 & 2.117 & 0.48257 & & $0 / 1$ & 1 \\
\hline Andrena minutula & -1.182 & -4.481 & 2.117 & 0.48257 & & $0 / 1$ & 3 \\
\hline Anthidium punctatum & -1.182 & -4.481 & 2.117 & 0.48257 & & $0 / 1$ & 1 \\
\hline Coelioxys conica & -1.182 & -4.481 & 2.117 & 0.48257 & & $0 / 1$ & 1 \\
\hline Colletes daviesanus & -1.182 & -4.481 & 2.117 & 0.48257 & & $0 / 1$ & 1 \\
\hline Halictus tumulorum & -1.182 & -4.481 & 2.117 & 0.48257 & & $0 / 1$ & 1 \\
\hline Hylaeus brevicornis & -1.182 & -4.481 & 2.117 & 0.48257 & & $0 / 1$ & 2 \\
\hline Megachile alpicola & -1.182 & -4.481 & 2.117 & 0.48257 & & $0 / 1$ & 1 \\
\hline Megachile lapponica & -1.182 & -4.481 & 2.117 & 0.48257 & & $0 / 1$ & 1 \\
\hline Megachile versicolor & -1.182 & -4.481 & 2.117 & 0.48257 & & $0 / 1$ & 1 \\
\hline Megachile willughbiella & -1.182 & -4.481 & 2.117 & 0.48257 & & $0 / 1$ & 1 \\
\hline Pemphredon inornata & -1.182 & -4.481 & 2.117 & 0.48257 & & $0 / 1$ & 1 \\
\hline Pemphredon wesmaeli & -1.182 & -4.481 & 2.117 & 0.48257 & & $0 / 1$ & 1 \\
\hline Melitta haemorrhoidalis & -0.788 & -3.337 & 1.760 & 0.54429 & & $1 / 2$ & 3 \\
\hline Trachusa byssina & -0.788 & -3.337 & 1.760 & 0.54429 & & $1 / 2$ & 4 \\
\hline Hylaeus communis & -0.762 & -2.501 & 0.977 & 0.39037 & & $3 / 5$ & 16 \\
\hline Andrena bicolor & 0.000 & -2.147 & 2.147 & 1.00000 & & $2 / 2$ & 5 \\
\hline Chelostoma campanularum & 0.000 & -2.895 & 2.895 & 1.00000 & & $1 / 1$ & 2 \\
\hline Dufourea dentiventris & 0.000 & -2.895 & 2.895 & 1.00000 & & $1 / 1$ & 3 \\
\hline Hylaeus hyalinatus & 0.000 & -2.895 & 2.895 & 1.00000 & & $1 / 1$ & 2 \\
\hline Lasioglossum albipes & 0.000 & -2.147 & 2.147 & 1.00000 & & $2 / 2$ & 5 \\
\hline Sphecodes geoffrellus & 0.788 & -1.760 & 3.337 & 0.54429 & & $2 / 1$ & 3 \\
\hline Coelioxys inermis & 1.182 & -2.117 & 4.481 & 0.48257 & & $1 / 0$ & 1 \\
\hline Hoplitis claviventris & 1.182 & -2.117 & 4.481 & 0.48257 & & $1 / 0$ & 1 \\
\hline Hylaeus angustatus & 1.182 & -2.117 & 4.481 & 0.48257 & & $1 / 0$ & 1 \\
\hline Hylaeus incongruus & 1.182 & -2.117 & 4.481 & 0.48257 & & $1 / 0$ & 1 \\
\hline Megachile centuncularis & 1.182 & -2.117 & 4.481 & 0.48257 & & $1 / 0$ & 1 \\
\hline Nomada flavoguttata & 1.182 & -2.117 & 4.481 & 0.48257 & & $1 / 0$ & 1 \\
\hline Sphecodes ferruginatus & 1.182 & -2.117 & 4.481 & 0.48257 & & $1 / 0$ & 1 \\
\hline Hylaeus confusus & 1.386 & -0.311 & 3.084 & 0.10943 & & $8 / 4$ & 19 \\
\hline Megachile ligniseca & 2.583 & -0.466 & 5.632 & 0.09684 & & $4 / 0$ & 4 \\
\hline
\end{tabular}


Table 2 (continued).

\begin{tabular}{|c|c|c|c|c|c|c|c|}
\hline & In (odds ratio) & $-\mathrm{Cl}_{95 \%}$ & $+\mathrm{Cl}_{95 \%}$ & $\mathrm{p}$-Value & & Freq. Pan/Net & No. of specimens \\
\hline \multicolumn{8}{|l|}{ SYRPHIDAE } \\
\hline Episyrphus balteatus & -4.796 & -7.691 & -1.901 & 0.00117 & ** & $1 / 11$ & 236 \\
\hline Sphaerophoria scripta & -4.654 & -7.799 & -1.509 & 0.00373 & ** & $0 / 10$ & 70 \\
\hline Chrysotoxum arcuatum & -4.217 & -7.298 & -1.136 & 0.00730 & ** & $0 / 9$ & 16 \\
\hline Helophilus pendulus & -4.217 & -7.298 & -1.136 & 0.00730 & ** & $0 / 9$ & 29 \\
\hline Eupeodes corollae & -3.855 & -6.904 & -0.806 & 0.01321 & * & $0 / 8$ & 24 \\
\hline Eristalis interrupta & -3.219 & -6.247 & -0.190 & 0.03724 & * & $0 / 6$ & 33 \\
\hline Eristalis pertinax & -3.219 & -6.247 & -0.190 & 0.03724 & * & $0 / 6$ & 17 \\
\hline Melanostoma scalare & -3.219 & -6.247 & -0.190 & 0.03724 & * & $0 / 6$ & 15 \\
\hline Sphaerophoria philantha & -3.219 & -6.247 & -0.190 & 0.03724 & * & $0 / 6$ & 14 \\
\hline Sphaerophoria virgata & -2.909 & -5.942 & 0.125 & 0.06018 & & $0 / 5$ & 10 \\
\hline Eristalis intricaria & -2.583 & -5.632 & 0.466 & 0.09684 & & $0 / 4$ & 4 \\
\hline Eristalis lineata & -2.583 & -5.632 & 0.466 & 0.09684 & & $0 / 4$ & 5 \\
\hline Platycheirus angustatus & -2.583 & -5.632 & 0.466 & 0.09684 & & $0 / 4$ & 7 \\
\hline Syrphus torvus & -2.583 & -5.632 & 0.466 & 0.09684 & & $0 / 4$ & 5 \\
\hline Syrphus vitripennis & -2.583 & -5.632 & 0.466 & 0.09684 & & $0 / 4$ & 5 \\
\hline Eristalis pseudorupium & -2.220 & -5.301 & 0.861 & 0.15780 & & $0 / 3$ & 3 \\
\hline Meliscaeva cinctella & -2.220 & -5.301 & 0.861 & 0.15780 & & $0 / 3$ & 5 \\
\hline Myathropa florea & -2.220 & -5.301 & 0.861 & 0.15780 & & $0 / 3$ & 3 \\
\hline Platycheirus granditarsis & -2.220 & -5.301 & 0.861 & 0.15780 & & $0 / 3$ & 13 \\
\hline Scaeva pyrastri & -2.220 & -5.301 & 0.861 & 0.15780 & & $0 / 3$ & 3 \\
\hline Syritta pipiens & -2.220 & -5.301 & 0.861 & 0.15780 & & $0 / 3$ & 29 \\
\hline Xylota tarda & -2.061 & -4.408 & 0.285 & 0.08515 & & $1 / 5$ & 8 \\
\hline Dasysyrphus tricinctus & -1.784 & -4.929 & 1.361 & 0.26632 & & $0 / 2$ & 2 \\
\hline Eristalis cryptarum & -1.784 & -4.929 & 1.361 & 0.26632 & & $0 / 2$ & 2 \\
\hline Helophilus hybridus & -1.784 & -4.929 & 1.361 & 0.26632 & & $0 / 2$ & 2 \\
\hline Paragus pecchiolii & -1.784 & -4.929 & 1.361 & 0.26632 & & $0 / 2$ & 2 \\
\hline Pipizella viduata & -1.784 & -4.929 & 1.361 & 0.26632 & & $0 / 2$ & 2 \\
\hline Platycheirus clypeatus & -1.784 & -4.929 & 1.361 & 0.26632 & & $0 / 2$ & 2 \\
\hline Syrphus ribesii & -1.784 & -4.929 & 1.361 & 0.26632 & & $0 / 2$ & 2 \\
\hline Volucella bombylans & -1.784 & -4.929 & 1.361 & 0.26632 & & $0 / 2$ & 2 \\
\hline Volucella pellucens & -1.784 & -4.929 & 1.361 & 0.26632 & & $0 / 2$ & 2 \\
\hline Xylota meigeniana & -1.784 & -4.929 & 1.361 & 0.26632 & & $0 / 2$ & 3 \\
\hline Chrysotoxum bicinctum & -1.609 & -3.503 & 0.284 & 0.09573 & & $2 / 6$ & 16 \\
\hline Baccha elongata & -1.182 & -4.481 & 2.117 & 0.48257 & & $0 / 1$ & 1 \\
\hline Blera fallax & -1.182 & -4.481 & 2.117 & 0.48257 & & $0 / 1$ & 1 \\
\hline Cheilosia longula & -1.182 & -4.481 & 2.117 & 0.48257 & & $0 / 1$ & 1 \\
\hline Cheilosia urbana & -1.182 & -4.481 & 2.117 & 0.48257 & & $0 / 1$ & 1 \\
\hline Cheilosia vernalis & -1.182 & -4.481 & 2.117 & 0.48257 & & $0 / 1$ & 2 \\
\hline Chrysogaster solstitialis & -1.182 & -4.481 & 2.117 & 0.48257 & & $0 / 1$ & 1 \\
\hline Chrysotoxum festivum & -1.182 & -4.481 & 2.117 & 0.48257 & & $0 / 1$ & 1 \\
\hline Didea intermedia & -1.182 & -4.481 & 2.117 & 0.48257 & & $0 / 1$ & 1 \\
\hline Eristalis picea & -1.182 & -4.481 & 2.117 & 0.48257 & & $0 / 1$ & 1 \\
\hline Eristalis tenax & -1.182 & -4.481 & 2.117 & 0.48257 & & $0 / 1$ & 1 \\
\hline Heringia vitripennis & -1.182 & -4.481 & 2.117 & 0.48257 & & $0 / 1$ & 1 \\
\hline Paragus tibialis & -1.182 & -4.481 & 2.117 & 0.48257 & & $0 / 1$ & 1 \\
\hline Parasyrphus lineolus & -1.182 & -4.481 & 2.117 & 0.48257 & & $0 / 1$ & 1 \\
\hline Parhelophilus consimilis & -1.182 & -4.481 & 2.117 & 0.48257 & & $0 / 1$ & 1 \\
\hline Platycheirus albimanus & -1.182 & -4.481 & 2.117 & 0.48257 & & $0 / 1$ & 1 \\
\hline Platycheirus europaeus & -1.182 & -4.481 & 2.117 & 0.48257 & & $0 / 1$ & 2 \\
\hline Platycheirus rosarum & -1.182 & -4.481 & 2.117 & 0.48257 & & $0 / 1$ & 2 \\
\hline Sphaerophoria chongjini & -1.182 & -4.481 & 2.117 & 0.48257 & & $0 / 1$ & 1 \\
\hline Sphaerophoria fatarum & -1.182 & -4.481 & 2.117 & 0.48257 & & $0 / 1$ & 1 \\
\hline Sphaerophoria interrupta & -1.182 & -4.481 & 2.117 & 0.48257 & & $0 / 1$ & 2 \\
\hline Sphaerophoria taeniata & -1.182 & -4.481 & 2.117 & 0.48257 & & $0 / 1$ & 3 \\
\hline Xylota florum & -1.182 & -4.481 & 2.117 & 0.48257 & & $0 / 1$ & 1 \\
\hline Xylota sylvarum & -1.182 & -4.481 & 2.117 & 0.48257 & & $0 / 1$ & 1 \\
\hline Sericomyia silentis & -1.099 & -2.827 & 0.630 & 0.21287 & & $6 / 9$ & 61 \\
\hline Xylota jakutorum & -0.511 & -2.514 & 1.492 & 0.61719 & & $2 / 3$ & 5 \\
\hline Cheilosia scutellata & 0.000 & -2.895 & 2.895 & 1.00000 & & $1 / 1$ & 2 \\
\hline Leucozona glaucia & 0.000 & -2.895 & 2.895 & 1.00000 & & $1 / 1$ & 2 \\
\hline Xylota segnis & 0.000 & -1.697 & 1.697 & 1.00000 & & $4 / 4$ & 11 \\
\hline Megasyrphus erraticus & 1.182 & -2.117 & 4.481 & 0.48257 & & $1 / 0$ & 1 \\
\hline
\end{tabular}

ing percentage of the total catch recorded in pan traps is $86 \%$ (bees, Wilson et al., 2008), 65\% (bees, Nielsen et al., 2011), 65\% (multi-taxa, Spafford \& Lortie, 2013), 35\% (multi-taxa, Popic et al., 2013), 33\% (multi-taxa, current study), 25\% (bumblebees, Wood et al., 2015) and 17\% (bees, Roulston et al., 2007). This striking imbalance in 
the catches using these two methods makes it extremely difficult to compare the results of studies using different methods and generally hampers the transferability of results. Therefore, not only pan trapping needs to follow a strict protocol (LeBuhn et al., 2016) but also sweep netting, in order to obtain similar sized catches using these two methods.

As pan-traps can attract pollinators even if there are no flowers in the vicinity, it might attract individuals that are only transient members of the pollinator assemblages at a site. Even if a proportion of the sweep netted individuals are transient at a site, it is not a major problem as the time spent sampling was short. Hence, in a low-resource landscape, the positive bias of pan traps might lead to misleading conclusions.

It is a matter of debate whether the biases are mainly in the pan-trap catches or the sweep-net catches, or both. In the absence of an unbiased sampling method, we can only speculate. But it is worthwhile considering a few reasons for a bias. First, colour preferences may influence the total pan trap catch. It is well-known that flower-visiting insects prefer particular colours, which is the reason why three different colours are normally used for pan-trapping (e.g. Kirk, 1984; Vrdoljak \& Samways, 2012; Joshi et al., 2015; Moreira et al., 2016; Sircom et al., 2018). The underlying mechanism of colour preference seems to be due to fundamental differences in the visual processing of different insects (Shrestha et al., 2019). In our study system, Lepturinae strongly preferred two of the three colours (blue, white) while Syrphidae only one (yellow; Berglund et al., in prep.), and such "double preferences" of Lepturinae would have boosted their numbers and the potential bias in the catches. Second, pan trapping is more likely to catch small specimens (Westphal et al., 2008) and under-sample large species (Cane, 2001) that may escape the traps more easily (Westphal et al., 2008). There was, however, no support for this scenario in the present data, irrespective of whether analyses were done on all species, or groups of species.

It is apparent that some taxa are more likely to be caught in either pan-traps or by sweep netting, as for no groups were the numbers of individuals caught by pan-traps and sweep netting correlated. Syrphidae as a group was more easily recorded using sweep netting and less likely to be recorded using pan-traps. It is unclear whether they are not attracted to the colours and shapes of the pan-traps used, or whether their flight and landing behaviour when approaching a pan-trap makes them less prone to be caught. Social Apoidea are large-bodied insects, which gives some support to the assumed pan-trap bias against large body sized insects (Cane, 2001; Westphal et al., 2008). On the other hand, both groups that were much better sampled using pan-traps, Cetoniidea and Lepturinae, are large species. Being beetles, their flight and landing behaviour is less precise than that of Syrphidae and Apoidea, which might increase their chance of being trapped by pan-traps. On balance, it seems the potential for a body-size bias needs to be evaluated for each group of insects. Nevertheless, we found no indication of significant relationships within the three groups evaluated, hence a body size bias is not a universal phenomenon.

Finally, it is worth considering the limitations of the current study, which was carried out only late in the season (early August) and resulted in a modest sample size (1775 specimens). An earlier study using pan traps in the same year (early June, early July) indicates that numbers of Apoidea caught remained high throughout the summer, Lepturinae increased and Syrphidae decreased (Berglund et al., in prep.). This means that combining data for different groups will be affected by phenology, but that groupand species-wise comparisons using both sampling methods would be less affected by phenology.

In conclusion, our results show that the two methods are fundamentally different in terms of what they catch, which complicates or even prevents meaningful comparison when different methods are used. These findings add to the difficulties of sampling and monitoring insects (cf. Westphal et al., 2008) and highlight the need for improved reporting of catches as well as standardized methods for pan-traps (LeBuhn et al., 2016). Our results also underscore the obvious point of letting the target taxa/taxon decide the method of sampling. Finally, we could not confirm an assumed body-size bias in the catches of pan-traps.

ACKNOWLEDGEMENT. The Oscar and Lili Lamm Memorial Foundation provided financial support.

\section{REFERENCES}

Aizen M.A., Garibaldi L.A., Cunningham S.A. \& Klein A.M. 2009: How much does agriculture depend on pollinators? Lessons from log-term trends in crop production. - Ann. Bot. 103: $1579-1588$.

Bartsch H., Binkiewicz E., RÅdén A. \& NAsibov E. 2009a: Nationalnyckeln till Sveriges flora och fauna. Tvåvingar: Blomflugor: Syrphinae. Diptera: Surphidae: Syrphinae. ArtDatabanken, SLU, Uppsala, 406 pp.

Bartsch H., Binkiewicz E., KlintbJer A., RÅdén A. \& Nasibov E. 2009b: Nationalnyckeln till Sveriges flora och fauna. Tvåvingar: Blomflugor: Eristalinae \& Microdontinae. Diptera: Syrphidae: Eristalinae \& Microdontinae. ArtDatabanken, SLU, Uppsala, 478 pp.

CAmpbell J.W. \& HanUla J.L. 2007: Efficiency of malaise traps and colored pan traps for collecting flower visiting insects from three forested ecosystems. - J. Insect Conserv. 11: 399-408.

CANE J.H. 2001: Habitat fragmentation and native bees: A premature verdict? - Conserv. Ecol. 5(1): 3, 10 pp.

Cane J.H., Minckley R.L. \& Kervin L.J. 2000: Sampling bees (Hymenoptera: Apiformes) for pollinator community studies: pitfalls of pan-trapping. - J. Kans. Entomol. Soc. 73: 225-231.

FaLK S. 2015: Field Guide to the Bees of Great Britain and Ireland. Bloomsbury, London, $336 \mathrm{pp}$.

Fitzpatrick U., Murray T.E., Paxton R.J., Breen J., Cotton D., SANTORUM V. \& BRown M.J.F. 2007: Rarity and decline in bumblebees - A test of causes and correlates in the Irish fauna. Biol. Conserv. 136: 185-194.

Gallai N., Salles J.M., Settele J. \& Vissière B.E. 2008: Economic valuation of the vulnerability of world agriculture confronted with pollinator decline. - Ecol. Econ. 68: 810-821. 
Grundel R., Frohnapple K.J., Jean R.P. \& Pavlovic N.B. 2011: Effectiveness of bowl trapping and netting for inventory of a bee community. - Environ. Entomol. 40: 374-380.

Ibbe M., Milberg P., Tunér A. \& Bergman K.O. 2011: History matters: Impact of historical land use on butterfly diversity in clear-cuts in a boreal landscape. - Forest Ecol. Manag. 261: $1885-1891$

Jonason D., Ibbe M., Milberg P., Tunér A., Westerberg L. \& BergMAN K.O. 2014: Vegetation in clear-cuts depends on previous land use: a century-old grassland legacy. - Ecol. Evol. 4: 4287-4295.

Jonason D., Bergman K.-O., Westerberg L. \& Milberg P. 2016 Land-use history exerts long-term effects on the flora in clearcuts. - Appl. Veget. Sci. 19: 634-643.

Joshi N.K., Leslie T., Rajotte E.G., Kammerer M.A., Otieno M. \& BidDinger D.J. 2015: Comparative trapping efficiency to characterize bee abundance, diversity, and community composition in apple orchards. - Ann. Entomol. Soc. Am. 108: 785-799.

KIRK W.D.J. 1984: Ecologically selective coloured traps. - Ecol. Entomol. 9: 35-41.

Klein A.-M., Vaissière B.E., Cane J.H., Steffan-Dewenter I., Cunningham S.A., Kremen C. \& Tscharntke T. 2007: Importance of pollinators in changing landscapes for world crops. - Proc. R. Soc. (B) 274: 303-313.

Kluster S. \& Peduzzi P. 2007: Global Pollinator Decline: A Literature Review. UNEP/GRID-Europe. URL: https://archiveouverte.unige.ch/unige:32258/ATTACHMENT01.

LeBuhn G., Droege S., Connor E., Gemmill-Herren B. \& Azzu N. 2016: Protocol to Detect and Monitor Pollinator Communities: Guidance for Practitioners. Food and Agriculture Organization (FAO), Rome, 64 pp.

Lindhe A., Jeppsson T. \& Ehnström B. 2010: Longhorn beetles in Sweden: changes in distribution and abundance over the last two hundred years. - Entomol. Tidskr. 131: 241-508.

MCCRAVY K. 2018: A review of sampling and monitoring methods for beneficial arthropods in agroecosystems. - Insects 9: $170,28 \mathrm{pp}$.

Milberg P., Bergman K.-O., Jonason D., Karlsson J. \& WestERBERG L. 2019: Land-use history influence the vegetation in coniferous production forests in southern Sweden. - Forest Ecol. Manag. 440: 23-30.

Moreira E.F., da Silva Santos R.L., Penna U.L., Angel-Coca C., DE Oliveira F.F. \& Viana B.F. 2016: Are pan traps colors complementary to sample community of potential pollinator insects? - J. Insect Conserv. 20: 583-596.

Namaghi H.S. \& Husseini M. 2009: The effects of collection methods on species diversity of family Syrphidae (Diptera) in Neyshabur, Iran. - J. Agr. Sci. Technol. 11: 521-526.
Nielsen A., Steffan-Dewenter I., Westphal C., Messinger O., Potts S.G., Roberts S.P.M., Settele J., Szentgyörgyi H., VaisSIĖre B.E., Vaitis M. ET Al. 2011: Assessing bee species richness in two Mediterranean communities: importance of habitat type and sampling techniques. - Ecol. Res. 26: 969-983.

Popic T.J., Davila Y.C. \& Wardle G.M. 2013: Evaluation of common methods for sampling invertebrate pollinator assemblages: net sampling out-perform pan traps. - PLoS ONE 8(6), e66665, $9 \mathrm{pp}$.

Potts S.G., Biesmeijer J.C., Kremen C., Neumann P., Schweiger O. \& KunIN W.E. 2010: Global pollinator declines: trends, impacts and drivers. - Trends Ecol. Evol. 25: 345-353.

Roulston T.H., SMith S.A. \& Brewster A.L. 2007: A comparison of pan trap and intensive net sampling techniques for documenting a bee (Hymenoptera: Apiformes) fauna. - J. Kans. Entomol. Soc. 80: 179-181.

Shrestha M., Garcia J.E., Chua J.H., Howard S.R., Tscheulin T., Dorin A., Nielsen A. \& Dyer A.G. 2019: Fluorescent pan traps affect the capture rate of insect orders in different ways. —Insects 10: 40, $12 \mathrm{pp}$.

Sircom J., Jothi G.A. \& PinKSEN J. 2018: Monitoring bee populations: are eusocial bees attracted to different colours of pan trap than other bees? - J. Insect Conserv. 22: 433-441.

Soвota G. \& Twardowski J. 2004: Variation in species spectrum of hover flies (Diptera: Syrphidae) in arable crops depending the collection methods. - Electron. J. Pol. Agr. Univ. 7(2): 8.

SpAFFORD R.D. \& LORTIE C.J. 2013: Sweeping beauty: is grassland arthropod community composition effectively estimated by sweep netting? - Ecol. Evol. 3: 3347-3358.

Tuell J.K. \& IsaAcs R. 2009: Elevated pan traps to monitor bees in flowering crop canopies. - Entomol. Exp. Appl. 131: 93-98.

Vanbergen A.J. \& Insect Pollinators Initiative 2013: Threats to an ecosystem service: Pressures on pollinators. - Front. Ecol. Environ. 11: 251-259.

VRDOLJAK S.M. \& SAMWAYs M.J. 2012: Optimising coloured pan traps to survey flower visiting insects. - J. Insect Conserv. 16: 345-354.

Westphal C., Bommarco R., Carré G., Lamborn E., Morison N., Petanidou T., Potts S.G., Roberts S.P.M., Szentgyorgyi H., Tscheulin T. ET AL. 2008: Measuring bee diversity in different European habitats and biogeographical regions. - Ecol. Monogr. 78: 653-671.

Wilson J.S., Griswold T. \& Messinger O.J. 2008: Sampling bee communities (Hymenoptera: Apiformes) in a desert landscape: are pan traps sufficient? - J. Kans. Entomol. Soc. 81: 288-300.

Wood T.J., Holland J.M. \& Goulson D. 2015: A comparison of techniques for assessing farmland bumblebee populations. Oecologia 177: 1093-1102.

Received June 1, 2019; revised and accepted October 17, 2019 Published online November 25, 2019 